\title{
Whales Might Also Be an Important Component in Patagonian Fjord Ecosystems: Comment to Iriarte et al.
}

\author{
Rodrigo Hucke-Gaete
}

Received: 5 November 2010/Accepted: 19 November 2010/Published online: 12 January 2011

This comment was not peer reviewed.

Comment to: Iriarte J.L., H.E. González, and L. Nahuelhual. 2010. Patagonian fjord ecosystems in Southern Chile as a highly, vulnerable region: problems and needs. AMBIO 39(7): 463-466.

Iriarte et al. (2010) provide an insightful report on fjord ecosystem functioning in southern Chile, highlighting its status as a global conservation priority and also a relevant site that provides important ecosystem services to humans. Among the latter, this area is considered a major $\mathrm{CO}_{2}$ sink region due to enhanced seasonal primary productivity. They also address relevant issues that could affect ecosystem integrity, and thus its functionality in the long run, such as the excessive nutrient input from the salmon farming industry and the effects of local and remote processes (including global change) on precipitation regimes and river discharges. These issues, among others, could have profound undesirable effects such as: increase of harmful algal bloom episodes, a shift in phytoplankton composition, an overall decrease in productivity and ultimately a reduction in the strength of the biological pump and carbon sequestration capacity by sinking biogenic material.

I completely adhere to their conclusions based on sound field and experimental science, but would like to strengthen their holistic view by calling attention to other mechanisms and pathways apparently not yet considered in their approach to understand Patagonian fjord ecosystems. These

The online version of the article commented upon can be found at doi: 10.1007/s13280-010-0049-9 mechanisms come from the potential impact that marine mammals, especially cetaceans, could have on "fertilizing" the photic zone with essential elements. After decades of being excluded from any consideration among classical oceanographic analyses and dismissed as insignificant in terms of total biomass (e.g., Llano 1977), recent evidence suggests that the impact of large cetaceans may in fact play an important role in marine ecosystems.

This comment intends to highlight those recent findings in the context of Chilean fjord ecosystems within the Chiloense Ecoregion and propose potentially fruitful collaborative directions for current and future research.

Nearly three decades ago, Kanwisher and Ridgway (1983) audaciously suggested at the time that cetaceans could play an analogous role to upwelling, "lifting nutrients from deep waters" and releasing fecal material "that tends to disperse rather than sink when it is released." This hypothesis did not flourish fully until Smetacek and Nicol (2005) indicated the plausible role of whales in recycling iron throughout the Southern Ocean, further emphasized later by Smetacek (2008) and Nicol et al. (2010) when suggesting that allowing the great whales to recover might actually increase Southern Ocean productivity through enhancing iron levels in the surface layer. Lavery et al. (2010) complemented the above by proposing that the removal of sperm whales (Physeter macrocephalus) in the Southern Ocean may have diminished this region's role as a reservoir for carbon. These pieces of evidence led Roman and McCarthy (2010) to suggest a novel and alternative mechanism for nutrient cycling in coastal systems, which they termed "the whale pump." In their own words: "[...] opposing the contribution of zooplankton [...] to the downward biological pump, cetaceans feeding deep in the water column effectively create an upward pump, enhancing nutrient availability for primary production in 
locations where whales gather to feed." This enhancement is by no means irrelevant or dismissible as previously thought. Based on their calculations and over the course of a year: "marine mammals release approximately $2.3 \times 10^{4}$ metric tons [of N] per year to the surface of the Gulf of Maine, more than all rivers combined and approximately the same as current coastal point sources" (Roman and McCarthy 2010). This can of course apply not only to nitrogen, but also to other limiting nutrients such as iron.

All of the above directs me to propose that the role of large whales might be an important and largely overlooked missing piece in the puzzle throughout some highly productive areas of the Patagonian fjords. Large aggregations of blue (Balaenoptera musculus), humpback (Megaptera novaeangliae), and sei (Balaenoptera borealis) whales have been documented to feed and nurse their young consistently during the austral summer and early autumn, particularly in the Gulf of Corcovado and adjacent waters (Hucke-Gaete et al. 2004, 2006, 2010). The remarkable coastal habits displayed by these whales in the study area, and their prevalence to concentrate recurrently for feeding in large numbers during well-defined areas and predictable time periods, make them an appealing biological model for exploring their overall influence on primary productivity dynamics.

Unfortunately, these coastal areas are increasingly being affected by impacts arising from human activities. In the aim of proposing viable management scenarios based on ecological (and economic) findings, it would be desirable to widen views and integrate research efforts that allow the enhanced understanding of ecological dynamics, thus generating solid grounds for proposing options that maintain healthy and functional ecosystems. The establishment of a legal figure such as a Multiple-Use Marine Protected Area (MUMPA), where an integral management plan takes into consideration human and ecological needs, while regulating the more intensive and/or polluting activities, might correspond to such a way forward. As a direct consequence, this might ensure the continued provisioning of ecosystem services. It is also desirable that the attainment of such conservation objectives is guided by consensus, participation, and support of local and indigenous communities, stakeholders, and authorities.

\section{REFERENCES}

Hucke-Gaete, R., L.P. Osman, C.A. Moreno, K.P. Findlay, and D.K. Ljungblad. 2004. Discovery of a blue whale feeding and nursing ground in southern Chile. Proceedings of the Royal Society of London Series B 271: S170-S173.

Hucke-Gaete, R., F. Viddi, and M. Bello. 2006. Marine conservation in southern Chile: The importance of the Chiloe-Corcovado region for blue whales, biological diversity and sustainable development, $109 \mathrm{pp}$. Imprenta América, Valdivia: Centro Ballena Azul (ballenazul.org) (in Spanish and English).

Hucke-Gaete, R., R. Álvarez, M. Navarro, J. Ruiz, P. Lo Moro, and A. Farías. 2010. Investigación para Desarrollo de Área Marina Costera Protegida Chiloé-Palena-Guaitecas, 786 pp. Informe Final de estudio financiado por FNDR-BID TURISMO Cód. BIP No. 30040215-0, Gobierno Regional de Los Lagos. Unidad técnica mandante: CONAMA. Ejecutado por Universidad Austral de Chile (in Spanish) [unpublished report available from: www.mma.gob.cl].

Iriarte, J.L., H.E. González, and L. Nahuelhual. 2010. Patagonian Fjord ecosystems in southern Chile as a highly, vulnerable region: Problems and needs. AMBIO 39: 463-466.

Kanwisher, J.W., and S.H. Ridgway. 1983. The physiological ecology of whales and porpoises. Scientific American 248: 110-120.

Lavery, T.J., B. Rounew, P. Gill, J. Seymour, L. Seuront, G. Johnson, J.G. Mitchell, and V. Smetacek. 2010. Iron defecation by sperm whales stimulates carbon export in the southern Ocean. Proceedings of the Royal Society of London Series B 277: 3527-3531. doi:10.1098/rspb.2010.0863.

Llano, G.A. (ed). 1977. Adaptations within Antarctic ecosystems. In Proceedings of the third SCAR symposium on antarctic biology, 1252 pp. Washington, DC: Smithsonian Institute.

Nicol, S., A. Bowie, S. Jarmon, D. Lannuzel, K.M. Meiners, et al. 2010. Southern ocean iron fertilization by baleen whales and Antarctic krill. Fish and Fisheries 11: 203-209.

Roman, J., and J.J. McCarthy. 2010. The whale pump: Marine mammals enhance primary productivity in a coastal basin. PLoS ONE 5(10): e13255. doi:10.1371/journal.pone.0013255.

Smetacek, V. 2008. Are declining Antarctic krill stocks a result of global warming or of the decimation of the whales? In Impacts of global warming on polar ecosystems, ed. C.M. Duarte, 46-83. Madrid, Spain: Fundación BBVA.

Smetacek, V., and S. Nicol. 2005. Polar ocean ecosystems in a changing world. Nature 473: 362-368.

\section{Rodrigo Hucke-Gaete $(\bowtie)$}

Address: Instituto de Ecología y Evolución, Universidad Austral de Chile, Casilla 567, Valdivia, Chile.

e-mail: rhucke@uach.cl 